\title{
Study on Smoking in School Students of Oujda City in Eastern Morocco
}

\author{
Maamri A* \\ Mohamed Premier University, Morocco
}

Submission: September 20, 2017; Published: October 23, 2017

*Corresponding author: Maamri A, Mohamed Premier University, FS Oujda, Morocco, Email: abdellatifm@hotmail.com

\section{Short Communication}

Smoking, a real public health problem, is at the center of medical news. It is a social scourge that is increasingly alarming, particularly in developing countries and particularly in the increasingly young population [1]. It is one of the causes of preventable morbidity and mortality. Its consequences on health are currently well known. However, its motivations are codified because they are individual, hence the difficulty of standardizing the measures of withdrawal [2]. The study we carried out at the in Oujda cityis part of a descriptive study exploring the first level which aims to obtain information by means of a written questionnaire in order to identify the rate of smokers, their characteristics, determine the factors influencing smoking in their homes and give indications on the level of knowledge of young people with regard to this cosmopolitan problem. The survey covered a sample of 208 students, which represented $1 / 10$ of the target population.

The results show that:

a) The overall rate of smokersis $13.04 \%$ of which $25 \%$ are girls.

b) $2 / 3$ of smokers (66.66\%) are regular smokers, the rest (33, 33\%) are occasional smokers.

c) An introduction to smoking at a relativel yearly age, $12.5 \%$ at the age of 11 and $50 \%$ at an age between $15-16$ years.

d) $91.4 \%$ of current smokers use tobacco products other than cigarettes, of which $42.85 \%$ of respondents admit they consume Chicha, while $8.57 \%$ of smokers said they are satisfied with only cigarettes.

e) Smokers are characterized by their disrupted and unsatisfactory schooling, $37.5 \%$ repeat once, $8.33 \%$ repeat several times.

f) Regarding accessibility to cigarettes:

i. $\quad 83.33 \%$ of smokers reported that they buy cigarettes in detail. ii. $\quad 37.5 \%$ of smokers reported that they provide cigarettes near high school.

g) "Pleasure" as the reason for giving up cigarettes occupies first place by $32.35 \%$ while "stress" is cited as reason for smoking second in $26.47 \%$.

h) Regarding the role of the media and advertising, among the smoked high school students surveyed, $62.5 \%$ observed tobacco advertisements on advertising boards, newspapers or television.

i) There is à link between tobacco use among high school students and those around them, because $89 \%$ of high school students have at least one smoker in their environment and $62.5 \%$ of whom are their best friend.

j) Young peoples knowledge of smoking remains insufficient and vague:

i. $\quad 69.02 \%$ of high school students have little knowledge about tobacco-related risks.

ii. More than half of high school students said they have no knowledge of the tobacco control law [3-18].

In the light of these findings and in order to safeguard the health of the population exposed directly or indirectly, we stress the urgent need to implement a tobacco control strategy that is particularly suited to young people and specifically to high school students.

\section{References}

1. André G, Chantal L, Hawa S, Diane V (2010) des professionnels actifs pour traiter le tabagisme et sa dépendance. Montréal, Québec, canada, bibliothèque et archives.

2. Bartal, Chaouki M, Charkaoui N, Charqaoui O, Chraibi S, et al. (1999) Le tabagisme et ses impacts, Direction de l'épidémiologie et de lute contre les maladies. Division des maladies non transmissible, Maroc, imprimerie Ilit.

3. Bartal M, Bouayad Z, Bahlaoui A, Naciri A, Mezianeel A tabagisme au Maroc: un aperçu de la campagne anti-tabac,Faculté de Médecine de Casablanca, Maroc. Faculté de Médecine de Casablanca, Maroc. 
4. Borgne A comment vaincre les dépendances tabagiques, hôpital Jean Verdier.

5. Campaign for Tobacco Free Kids (2008) les dangers de tabagisme chez les jeunes, consulté le 16 octobre 2010, pp.1-2.

6. Enquête sur le tabagisme au Maroc (2007).

7. Expertise collective Inserm-Tabagisme (n.d), Prise en charge chez les étudiants, consultés le 20 octobre 2010 p.7.

8. Francis T (2001) Association pour les droits de non fumeurs (canada), Institut nationale de prévention et d'éducation pour la santé.

9. Institut nationale de prévention et d'éducation pour la santé [INPES] (2002) Campagne de prévention du tabagisme.

10. Institut nationale de prévention et d'éducation pour la santé [INPES] (2003) Tabac actualités, $n^{\circ} 43$, Lettre mensuelle d'informations sur les effets du tabagisme et le sevrage tabagique.

11. Institut national de prévention et d'éducation pour la santé [INPES] (2008) Ne laissez pas le tabac décider pour vous. Dossier de presse p.4.

12. Lydia F, Bonnet A, Teyssier M, Apter M, Pedinielli J, et al. (2004) Tabagisme et états métamotivationnels chez des adolescents lycéens, Université de Provence, Aix-Marseille, France.
13. Organisation mondiale de la santé (2009) rapport sur l'épidémie mondiale de tabagisme Pour vivre sans tabac.

14. Organisation mondiale de la santé (2010) le tabagisme passif serait al'origine de 600.000 décès par an.

15. Bensalah M (2010) connaissances, attitudes et comportement des écoliers vis-à-vis du tabagisme à la préfecture d'Oujda, pour l'obtention du doctorat en médecine, université sidi Mohamed ben Abdellah, faculté de médecine et de pharmacie, Fès, Maroc.

16. El Bahi E, El Houari H, Arif M (2007) Tabagisme chez les lycéens : étude dans trois lycées d'Essaouira, mémoire pour l'obtention du diplôme d'état de 1 er cycle option infirmier polyvalent, institut de formation aux carrières de santé, Essaouira, Maroc.

17. Lottin P (2000) Evolution selon l'age du comportement tabagique des jeunes parisiens. In : Lottin $P$ (ed.), thèse de doctorat en médecine, université paris 7, denis Diderot, faculté de médecine, paris, France, p. 115.

18. Mhalla S (2009) le tabagisme en milieu scolaire dans la ville de Monastir : enquête réalisé auprès 1032 élèves de l'enseignement secondaire thèse de médecine, Université du centre faculté de médecine de Monastir, Tunisie.

\section{Your next submission with Juniper Publishers} will reach you the below assets

- Quality Editorial service

- Swift Peer Review

- Reprints availability

- E-prints Service

- Manuscript Podcast for convenient understanding

- Global attainment for your research

- Manuscript accessibility in different formats

( Pdf, E-pub, Full Text, Audio)

- Unceasing customer service

Track the below URL for one-step submission https://juniperpublishers.com/online-submission.php 